\title{
HUBUNGAN PENGUASAAN GAYA BAHASA METAFORA DENGAN KETERAMPILAN MENULIS NASKAH PIDATO EKSTEMPORAN
}

\author{
Eli Marlina Harahap, Lili Herawati Parapat, \& Linda Sari \\ Program Studi Pendidikan Bahasa Indonesia \\ Universitas Muhammadiyah Tapanuli Selatan Padangsidimpuan \\ email: eli.marlina@um-tapsel.ac.id' lili.herawati@um-tapsel.ac.id
}

\begin{abstract}
Abstrak
Penelitian ini bertujuan untuk mengetahui hubungan penguasaan gaya bahasa metafora terhadap keterampilan menulis naskah pidato ekstemporan siswa kelas $\mathrm{X}$ SMK Muhammadiyah 14 Siabu. Metode penelitian yang digunakan adalah metode deskriftif jenis korelasional, rumus yang dipakai yaitu Suharsimi Arikunto, Populasi penelitian adalah seluruh siswa kelas X SM1K Muhammadiyah 14 Siabu yang berjumlah 68 siswa. Maka seluruh jumlah populasi dijadikan sampel karna jumlah populasi yang kurang dari 100 siswa. Untuk menjaring kedua data digunakan instrument tes penguasaan gaya bahasa terhapat keterampilan menulis naskah pidato ekstemporan. Kedua tes objektif berbentuk pilihan berganda berjumlah 20 soal dan essay yang berjumlah 1 soal. Untuk mengetahui hubungan kedua variabel Y digunakan rumus koefisien determinasi $\mathrm{r}^{2}$. Berdasarkan analisis tersebut diperoleh skor tertinggi untuk masing-masing variabel 80 dan skor terendah 60, dengan nilai rata-rata 64,48 untuk variabel $\mathrm{X}$ dan 67,72 variabel $\mathrm{Y}$. Pada data yang telah diajukan maka taraf signifikasi $95 \%$ yaitu 0,388 0,374. Dengan demikian hipotesis yang diajukan dapat diterima kebenarannya. Berdasarkan hasil tersebut maka hubungan penguasaan gaya bahasa metafora dengan keterampilan menulis naskah pidato ekstemporan berkategori "'Baik".
\end{abstract}

Kata kunci : Gaya bahasa metafora, pokok pembahasan pidato ekstemporan.

PENDAHULUAN

Gaya bahasa dan penulisan merupakan salah satu unsur yang menarik dalam sebuah bacaan. Satiap penulis mempunyai gaya bahasa yang berbeda-beda dalam menuangkan setiap ide tulisannya. Setiap tulisan yang dihasilkan nantinya mempunyai gaya bahasa yang dipengaruhi oleh penulisnya, sehingga dapat dikatakan bahwa, watak seorang penulis sangat mempengaruhi sebuah karya yang ditulisnya. Pada prinsipnya metafora merupakan sejenis analogi, suatu komparasi terhadap kedua hal yang dalam beberapa segi mengandung persamaan. Penggunaan gaya bahasa tidak ada bedanya dengan seseorang 
yang menciptakan puisi, dituntut kemahiran di dalam tarik ataupun kemahiran dalam memilih gaya bahasa agar penggunaan bahasa tampak menarik dan indah, sehingga pendengar atau pembaca tertarik untuk dapat memahami maksud serta tujuan tulisan tersebut agar tidak terjadi kasalah pahaman antara penulis dengan pendengar atau pembaca.

Berpidato pada dasarnya merupakan kegiatan mengungkapkan pikiran dalam bentuk kata-kata (lisan) yang ditujukan kepada orang banyak dalam sebuah forum, sebelum berpidato perlu disiapkan naskah pidato tersebut. Pidato adalah berbicara dihadapan khalayak ramai atau masyarakat banyak dengan maksud dan tujuan yang bermacammacam. Berpidato, ceramah dan diskusi dihadapan khalayak ramai kelihatannya remeh dan mudah, akan tetapi perlu bimbingan dan latihan yang matang. Untuk mendapatkan hasil yang positif sekaligus maksud yang terkandung dalam hati sanubari dapat diutarakan dengan tuntas, maka sebelumnya persiapkanlah terlebih dahulu bahan-bahan yang akan disampaikan, misalnya ditulis atau diketik. Kalau perlu supaya kita mengadakan latihan di depan kaca dengan mempraktekkan gaya dengan gerak, dan kalau perlu bisa berlatih di atas meja atau di tempat yang tinggi. Siswa diharapkan dapat menguasai dan menggunakan gaya bahasa metafora dengan tepat dalam kalimat disetiap penulisan pidato ekstemporan.

Bedasarkan temuan di lapangan menunjukkan bahwa kemampuan menulis naskah pidato ekstemporan siswa masih sangat rendah. Karena penguasaan gaya bahasa metafora pada siswa Kelas X SMK Muhammadiyah 14 Siabu masih jauh dari yang diharapkan. Siswa belum mampu menguasai atau belum banyak pengetahuan tentang gaya bahasa metafora. Hal ini menimbulkan kekuatiran penulis, karena siswa akan sulit dalam penulisan.

\section{PEMBAHASAN}

Keraf (1980:112) mengatakan Gaya atau gaya bahasa dikenal dalam retorika dengan istilah style kata style diturunkan dari kata Latin stilus, yaitu semacam alat untuk menulis pada lempengan lilin. Keahlian menggunakan alat ini akan mempengaruhi jelas tidaknya tulisan pada lempengan tadi. Kelak pada 
waktu penekanan dititikberatkan pada keahlian untuk menulis indah, maka style lalu berubah menjadi kemampuan dan keahlian untuk menulis atau mempergunakan katakata secara indah.

Karena perkembangan itu, gaya bahasa atau style menjadi masalah atau bagian dari diksi atau pilihan kata yang mempersoalkan cocok tidaknya pemkaian kata, frasa atau klausa tertentu untuk menghadapi situasi tertentu. Sebab itu persoalan gaya bahasa meliputi semua hirarki kebahasaan: pilihan kata secara individual, frasa, klausa, dan kalimat, bahkan mencakup pula sebuah wacana secara keseluruhan.

Keraf (1980:113). Sebuah gaya bahasa yang baik harus mengandung tiga unsur berikut: kejujuran, sopansantun, dan menarik. Sumadiria (2006:148) Metafora adalah pemakaian kata-kata bukan arti yang sebenarnya, melainkan sebagai lukisan yang berdasarkan persamaan atau perbandingan Poerwadarminta (Sumadiria 2006:148). Metafora adalah sejenis gaya bahasa perbandingan yang singkat, padat, tersusun rapi. Di dalamnya terlihat dua gagasan. Gagasan yang pertama adalah suatu kenyataan sesuatu yang dipikirkan, sesuatu yang menjadi objek. Gagasan yang kedua merupakan perbandingan terhadap kenyataan pertama tersebut Tarigan (Sumadiria 2006:148).

Pada metafora, kata-kata
penyebut yang secara eksplisit menunjukkan adanya perbandingan. Gaya bahasa metafora salah satu bagian dari gaya bahasa kiasan yang bertujuan untuk mengindahkan suatu kalimat. Metafora adalah semacam analogi yang membandingkan dua hal secara langsung atau pengandaian dua hal secara langsung, tetapi dalam bentuk yang singkat: pahlawan disebutbunga bangsa, buaya darat, buah hati ,cindera mata, dan bulan disebut putri malam, yang membantu dalam aksi kejahatan sering disebut kaki tangan, orang yang mencuru disebut panjang tangan, oleh-oleh disebut buah tangan, orang yang celaka akibat perbuatannya sendiri disebut buah simalakama dan sebagainya.

Metafora sebagai perbandingan langsung tidak mempergunakan kata: seperti, bak, bagai, bagaikan, dan sebagainya, sehingga pokok pertama langsung dihubungkan dengan pokok 
kedua. Proses terjadinya sebenarnya sama dengan smile tetapi secara berangsur-angsur keterangan mengenai persamaan dan pokok pertama dihilangkan, misalnya:

Pemuda adalah seperti bunga bangsa------- Pemuda adalah bunga bangsa, pemuda ------

--Bunga bangsa

Orang itu seperti buaya darat.--------- Orang itu adalah buaya darat.

Orang itu -------buaya darat.

Bila dalam sebuah metafora, kita masih dapat menentukan makna dasar dari konotasinya sekarang, maka metafora itu masih hidup. Tetapi kalau kita tidak dapat menentukan konotasinya lagi, maka metafora itu sudah mati, sudah merupakan klise.

\section{Perahu itu menggergaji} ombak.

Mobilnya batuk-batuk sejak pagi tadi.

Pemuda pemudi adalah bunga

\section{bangsa.}

Kata- kata menggergaji, batuk-batuk, bunga dan bangsa masih hidup dengan arti aslinya. Sebab itu, penyimpangan makna seperti terdapat dalam kalimat-kalimat di atas merupakan metafora yang hidup. berlayar, berkembang, jembatan dan sebagainya. Metafora semacam ini adalah metafora mati. Dengan matinya sebuah metafora, kita berada kembali di depan sebuah kata yang mempunyai denotasi baru. Metafora semacam ini dapat berbentuk sebuah kata kerja, kata sifat, kata benda, frasa atau klausa: menarik hati, memegang jabatan, mengembangkan, menduga, dan sebagainya. Sekarang tidak ada orang yang berfikir bahwa bentukbentuk itu tadinya adalah metafora.

Persamaan adalah sejenis metafora yang merupakan suatu analogi eksplisit yang ditandai oleh kata seperti, sebagai, bak, seumpama, dan sejenis.

Keraf menjelaskan bahwa metafora tidak selalu harus menduduki predikat, tetapi dapat juga menduduki fungsi lain seperti subjek, objek, dan sebagainya dalam (Keraf:1996:139). Sejalan dengan Keraf, Wahab membagi metafora berdasarkan segi sintaksis menjadi tiga kelompok, yaitu (1) metafora nominatif, (2) metafora predikatif, dan (3) metafora kalima (Abdul Wahab, 1990: 141-177).

Empat keterampilan berbahasa yang meliputi yaitu: menyimak, berbicara, membaca, dan menulis. 
Katerampilan menulis Byrne (Saddhono 2014:163) pada hakikatnya bukan sekadar kemampuan menulis simbol-simbol grafis sehingga berbentuk kata, dan kata-kata disusun menjadi kalimat menurut peraturan, melainkan keterampilan menulis adalah kemampuan menuangakan buah pikiran ke dalam bahasa tulis melalui kalimat-kalimat yang dirangkai secara utuh, lengkap, dan jelas sehingga buah pikiran tersebut dapat dikomunikasikan kepada pembaca dengan berhasil. Keterampilan menulis menuntut kemampuan menggunakan pola-pola bahasa secara tertulis untuk mengungkapkan suatu gagasan ini. Keterampilan menulis ini mencakup berbagai kemampuan, misalnya kemampuan mengorganisasikan wacana dalam bentuk karangan, kemampuan menggunakan gaya bahasa yang tepat dan pilihan kata serta yang lainnya.

Belajar menulis yang baik memerlukan suatu metode, salah satu metode yang dapat dipakai adalah dengan latihan yang lama dan terusmenerus. Proses menulis sekurangkurangnya mencakup lima, 1. isi karangan, 2. bentuk karangan, 3. tata bahasa, 4. gaya, 5. ejaan dan tanda baca, dalam buku (David 1974:6769).

$\begin{array}{rrr}\text { Langkah } & \text { awal dalam } \\ \text { mempersiapkan } & \text { suatu } & \text { tulisan }\end{array}$
sebaiknya dilakukan dengan beberapa tahapan seperti:

1. Persiapan (preparation), perencanaan tulisan, b) menyusun kerangka tulisan (outline), c) mengumpulkan bahan-bahan, d) menemukan idiom yang menarik (eye catching), e) menentukan kata kunci (key word), f) memperkirakan konsumer bacaan.

2. Tahapan penulisan (writing) seperti: a) mengembangkan kerangka tulisan, b) menghilangkan unsur subjektifitas, c) harus objektif, faktual dan logis, d) konsisten, e) baca kembali setelah menyelesaikan satu paragraf, f) percaya diri akan yang telah ditulis.

3. Tahapan penyuntingan (editing) seperti: a) mencatat kesalahankesalahan pada kata ,frasa, klausa, kalimat, dsan paragraf, tanda baca, dan ejaan, b) perhatikan kohesi dan koherensi (paragraf dan seluruh tulisan), c) mereview 
kembali tulisan secara

keseluruhan.

Maulana (1999:14) Pidato adalah penyampaian gagasan, pikiran, atau informasi kepada orang banyak baik secara lisan maupun tulisan, dengan cara-cara tertentu. Tetapi pidato juga dapat diartikan sebagai seni membujuk seperti yang dikatakan oleh Aristoteles, "the art of persuasion”. Jadi, orang dikatakan berpidato secara bail dan berhasil apabila dai mampu membujuk para pendengar untuk memahami, menerima atau mematuhi pesan-pesan yang berupa informasi, ide atau pikiran. Balam pelaksanaan atau pendapat lainnya secara lisan dimuka umum. Oleh karana itu, dalam berpidato terkadapat tiga unsur, yaitu:

1. Pembicara yang menyampaikan isi pidato (komunikator)

2. Isi pembicaraan atau isi pidato yang disampaikan secara lisan

3. Pendengar atau hadirin yang menangkap isi pidato (komunikan)

Baik pada zaman dahulu, sekarang maupun masa yang akan datang pidato tetap akan memegang perenan penting detengah masyarakat.
Orang yang mempyunayai keahlian berpidato dengan mudah dapat membeberkan ide-idenya sehingga dapat diterima oleh para pendengarnya dengan mudah. Dengan demikian secara mudah kita ketahui orangorang yang ahli pidato yang dapat menguasai massa.

Keahlian berpidato memang tidak dapat diabaikan oleh penata masyarakat atau pemimpin, karena kemampuan ini sangat berguna untuk mengadakan komunikasi langsung dengan khalayak. Maulana (1999:16) Tujuan pidato tergantung dari keadaan dan apa yang dikehendaki oleh pembicara. Namun secara umum tujuan pidato dapat dibadakan menjadi tiga, yaitu: Memberitahukan, Menghibur atau menyenangnyenangkan, dan Membujuk atau mempengaruhi

Bila pidato bertujuan memberitahukan, maka reaksi yang diharapkan oleh pembicara ialah agar para pendengar paham atau mengerti terhadap apa yang diuraikanoleh pembicara. Jadi, setelah pidato selesai, diharapkan para pendengar memjadi tahu terhadap sesuatu yang sebelumnya kurang paham. Karena itu 
pembicaraan harus mengutamakan kejelasan isi pidato.

Pidato yang bertujuan untuk membujuk atau mempengaruhi pendengar. Dalam pidato ini pembicara berusaha mendorong, meyakinkan, dan akhirnya mengajak pendengar untuk melakukan sesuatu atau tidak melakukan sesuatu seperti yang dikehendaki oleh si pembicara. Pembicara mendorong pendengar, artinya ia berusaha memberi semangat dan membangkitkan kegairahan. Jadi berusaha membakar emosi para pendengar, pembicara meyakinkan pendengar, artinya pembicara berusaha mempengaruhi keyakinan atau sikap mental pendengar bahwa ini baik dan itu tidak baik.

Contohnya:

Topik : Sedekah

Topik umum : Membujuk

Topik khusus : Agar pendengar rajin bersedekah kepada yang kurang mampu.

Jenis pidato terbagi atas empat macam yaitu: Pidato Metode Naskah, Pidato Metode Menghafal, Pidato Metode Impromtu atau Metode Spontanitas, Pidato Metode
Ekstemporan atau Penjabaran Kerangka

Metode ini dianggap paling efektif diantara ketiga metode di atas. Karena itu metode ini sangat dianjurkan.

Metode ini merupakan sebelum berpidato, sang pembicara harus menyiapkan garis-garis besar isi pidato dengan cara menuliskan hal-hal yang dianggap penting. Penulis isi pidato itu tidak perlu secara utuh, tetapi cukup menuliskan pokok-pokok pembicaraan atau kerangkanya saja, dan pengembangan kerangka itu langsung saja disusun pada waktu berpidato. Dengan kata lain, kerangkanya sudah disiapkan, tetapi "dagingnya" diberikan secara spontanitas dalam berpidato kerangka dan catatan-catatan tadi hanya digunakan untuk menghafalkan dan mengingat-ingat urutan isi pidato.

Kebaikan metode ini adalah pembicara dapat melihat urutan isi pidato atau hal-hal lain jika lupa. Kebaikan yang lain pembicara mempunyai kesempatan yang luas untuk membina kontak batin dengan pendengarnya sehingga pidato lebih komunikatif, dan pembicara dengan 
mudah dapat menyesuaikan dengan reaksi-reaksi pendengar.

Maulana (1999:34) Metode pidato ekstemporan ini merupakan sebelum berpidato, sang pembicara harus menyiapkan garis-garis besar isi pidato dengan cara menuliskan hal-hal yang dianggap penting. Penulis isi pidato itu tidak perlu secara utuh, tetapi cukup menuliskan pokok-pokok pembicaraan atau kerangkanya saja, dan pengembangan kerangka itu langsung saja disusun pada waktu berpidato. Naskah pidato adalah sejenis karangan, oleh karena itu, persyaratan yang dilakukan untuk suatu karangan berlaku juga untuk naskah pidato. Naskah pidato bertolak dari suatu ide atau gagasa. Ide tersebut dikembangkan dengan berbagai penjelasan, uraian, dan contoh-contoh agar mudah dipahami.

Saddhono (2014:180) Secara garis besar, naskah pidato terdiri dari tiga bagian, yaitu: 1) pembukaan (pendahuluan), 2) isi (uraian pokok permasalahan), 3) kesimpulan (penutup). Pidato berisi uraian tenteng suatu gagasan, dibuka dengan memaparkan latar belakang masalah dan permasalahan yang ingin dikemukakan.

Selanjutnya, dikemukakan uraian tentang masalah itu secara mendalam. Pada bagian akhir, disampaikan kesimpulan serta saran.

Bagi mereka yang masih belajar berpidato, naskah tertulis ini dibaca dengan bersuara. Naskah pidato adalah sebuah karangan yang berisi tulisan yang memuat segala masalah yang akan diuraikan di dalam pidato. Isi naskah pidato harus disusun secara teratur dan berurutan. Namun bagi orang yang sudah biasa berpidato sebaiknya tidak menulis dan membaca seluruh naskah pidato, tetapi cukup dengan membuat catatancatatan kecil saja tentang beberapa materi pokok yang akan dipidatokannya. Untuk pidato-pidato yang bersifat yuridis formal, yang mengemukakan data-data konkret, naskah pidato secara lengkap itu sangat diperlukan. Dari keterangan di atas, dapat ditarik simpulan bahwa berpidato ini banyak sekali variasinya.

Orang yang ahli dalam berpidato biasanya tidak merasa cukup dengan membaca naskah itu saja, tetapi di sana sini selalu diselingi dengan variasi-variasi, humor-humor yang ada pada umumnya tidak ditulis dalam naskah. Ini dimaksudkan untuk 
menarik dan menimbulkan minat hadirin serta menghadiri kemajuan.

Satu hal perlu yang diperhatikan ialah bahwa antara berpidato secara langsung dan berpidato yang sepenuhnya terpaku pada teks atau naskah, efek psikologisnya besar sekali. Sebab, bila berpidato dengan terpaku membaca teks atau naskah, seolah-olah tidak ada hubungan emosional antara pembicara dengan objek permasalahan yang dibicarakan, sehingga dengan objek permasalahan yang dibicarakan, sehingga menimbulkan rasa bosan pada pendengarnya.

Naskah pidato biasanya dibuat dengan susunan sebagai berikut: (a) pembukaan, (b) pendahuluan, (c) isi pokok, (d) simpulan, (e) harapan, (f) penutup. Untuk lebih jelasnya dapatdisimak uraian berikut ini:

Berikut contoh pidato ekstemporan:

\section{Contoh Naskah $\quad$ Pidato}

\section{Ekstemporan}

Judul : Teknologi Yang Semakin

Canggih

Tema : Cara Menggunakan Teknologi

Yang Baik

Bismillahirrohmnirrohim
"Asslamualaikum Wa Rahmatullahi

\section{Wa Barakaatuh"}

Salam sejahtera bagi kita semua

Bapak ibu guru yang saya hormati, dan para bunga bangsa yang senantiasa semangat seterusnya teman-teman semua yang saya banggakan dan selalu berlapang dada. Marilah kita bersama-sama sampaikan puji syukur kehadirat Tuhan Yang Maha Esa, karena atas berkat rahmat dan hidayahnyalah kita dapat berkumpul di tempat ini dalam keadaan sehat tanpa kekurangan suatu apapun. Hadirin yang berbahagia, di zaman globalisasi sekarang ini kita seakan semakin dimanjakan oleh teknologi yang semakin canggih.

Marilah sejenak kita melihat kehidupan disekitar kita yang semakin terpengaruh oleh perkembangan teknologi. Saya beri contoh saja internet, teknologi ini sekarang semakin mudah diakses oleh siapapun baik tua ataupun muda. Jika kita mau berpikir lebih terbuka, sebenarnya ada sejuta manfaat yang bisa kita peroleh dari internet. Contohnya saja kita bisa mendapatkan banyak informasi, komunikasi yang semakin mudah, bahkan telah banyak orang yang menjadi kaya karena internet. Namun sayangnya banyak pihak yang menyalahgunakan teknologi internet ini, contohnya saja semakin maraknya pornografi, penipuan, mengajarkan untuk menjadi buaya darat dan sebagainya.

Internet juga menjadi salah satu gerbang masuknya budayabudaya asing yang kadang tidak sesuai dengan budaya kita. Kita bisa lihat buah hati kita yang sudah semakin teracuni oleh budaya barat yang sangat bertolak belakang dengan budaya Indonesia sebagai negeri timur yang sangat menjunjung tinggi norma 
kesopanan. Kita bisa lihat pemudapemuda kita yang sepertinya sangat bangga mengenakan pakaian-pakaian yang serba minim yang sebenarnya tidak sopan menurut budaya kita.

Oleh karena itu, hadirin yang saya hormati, cotohnya yang sebagai ibu rumah tangga kita harus pandaipandai menjaga anak kita agar bisa menggunakan internet dengan baik, kalau bisa kita harus memata-matainya dalam pergaulannya, dan terus berikan dia nasehat yang baik, jika anak itu susah dinasehati jangan mudah naik darah. Pandai-pandailah menyaring segala hal yang kita dapat di era globalisasi sekarang ini. Budaya asing sebenarnya tak semuanya buruk, namun kita harus bisa memilah mana yang baik dan mana yang buruk bagi kita. Akhir kata, saya ucapkan terimakasih atas perhatian hadirin. Saya mohon maaf jika ada kata-kata yang menyinggung perasaan hadirin.

Sebagai akhir kata kami ucapkan Terima kasih,

wassalamualaikum warahmatullahi wabarokatuh.

\section{KETERANGAN}

1. Dalam paragraf pertama terdapat gaya bahasa metafora bunga bangsa artinya sebagai generasi.

2. Dalam paragraf kedua terdapat gaya bahasa metafora buaya darat artinya sebagai laki-laki sihidung belang.

3. Paragraf ketiga terdapat gaya bahasa metafora buah hati artinya anak-anak.

4. Dalam paragraf keempat terdapat gaya bahasa metafora memata- matainya dan naik darah artinya, memantau dan marah.

\section{METODOLOGI PENELITIAN}

Penelitian ini dilaksanakan di Kelas X SMK Muhammadiyah 14 Siabu Kecamatan Siabu, jalan Medan Padang. Pelaksanaan penelitian pada bulan Juli sampai dengan September 2018. Adapun yang menjadi populasi dalam penelitian ini siswa kelas $\mathrm{X}$ SMK Muhammadiyah 14 Siabu yang berjumlah 68 siswa. Sampel pada penelitian ini adalah yang berjumlah 68 siswa. Penelitian yang digunakan adalah metode deskriptif (memberikan gambaran tentang kedua variabel).

Metode deskriptif pada penelitian ini adalah bentuk korelasional yaitu melihat gambaran di antara kedua variabel yaitu antara variabel $X$ (penguasaan gaya bahasa metefora) dan variabel Y (keterampilan menulis naskah pidato ekstemporan). Adapun hubungan kedua variabel tersebut dapat digambarkan sebagai berikut:

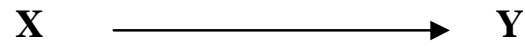

Keterangan: X: Sebagai variabel bebas yaitu penguasaan gaya bahasa metafora. 
Y: Sebagai variabel terikat yaitu keterampilan menulis naskah pidato ekstemporan

Berdasarkan kedua variabel di atas dapat dijelaskan bahwasanya variabel $(\mathrm{X})$ sebagai variabel bebas yaitu penguasaan gaya bahasa metafora sedangkan variabel (Y) sebagai variabel terikat yaitu keterampilan menulis naskah pidato ekstemporan.

Instrumen penelitian yang digunakan adalah tes dan non tes.

Untuk mengumpul data dari kedua variabel dibuat pen-skoran yakni jika siswa menjawab dengan benar diberi skor 5 (lima) sedangkan jika salah diberi skor 0 (nol). Maka rentang nilai antara 0 sampai dengan 100. Sedangkan nilai yang mungkin dicapai atau nilai tertinggi adalah nilai 5 point jika benar. pengumpulan data untuk mengetahui skor kemampuan menulis naskah pidato ekstemporan dibuat tes unjuk kerja dengan 4 indikator yaitu: Memahami tema pidato, Memahami isi pidato , Memahami unsur-unsur pidato, Memahami gaya bahasa sesuai dengan isi pidato
Untuk melakukan analisis data terdapat apa yang telah dikumpulkan maka ada dua tahap yang dilakukan yaitu: Analisis deskriptif, Analisis statistik.

\section{HASIL PENELITIAN}

Sebelum melakukan analisis terhadap kedua variabel penelitian yakni aplikasi penguasaan gaya bahasa metafora sebagai variabel $\mathrm{X}$ dan kemampuan menulis naskah pidato ekstemporan sebagai variabel $\mathrm{Y}$ diperoleh data dari lapangan dengan langkah-langkah sebagai berikut:

1. Mengolah data tes aplikasi menjadi nilai siswa.

2. Mengolah data tes kemampuan menulis naskah pidato ekstemporan menjadi nilai siswa setelah semua data diperoleh, selanjutnya dimasukkan kedalam tabel untuk mempermudah analisis datanya.

\section{Pengolahan Data Aplikasi Penguasaan Gaya Bahasa Metafora}

Berdasarkan data yang dikumpul dapat dilihat skor tertinggi aplikasi penggunaan penguasaan gaya bahasa metafora adalah 80 dan 
terendah 60. Nilai rata-rata pada skor yang diperoleh skor di atas adalah:

$M=\frac{\sum X}{\mathrm{~N}}$

$M=\frac{4385}{68}$

$M=64,48$

Setelah diperoleh skor hasil data penilaian dan nilai rata-rata kemudian diitentukan tingkat kualifikasi aplikasi penggunaan gaya bahasa metafora dengan Kriteria sebagai berikut:

Tabel 4.2

Tingkat Kriteria Penilaian

\begin{tabular}{|c|c|c|}
\hline No & Nilai & Kriteria \\
\hline 1. & $80-100$ & Sangat baik \\
\hline 2. & $60-79$ & Baik \\
\hline 3. & $50-59$ & Cukup \\
\hline 4. & $0-49$ & Gagal \\
\hline
\end{tabular}

Sesuai dengan rata-rata aplikasi penggunaa penguasaan gaya bahasa metafora yang diperoleh siswa yaitu 64,48 maka tingkat rata-rata siswa pada kategori "Baik"

\section{Pengolahan}

Data

Kemampuan

Menulis

Naskah Pidato Ekstemporan

Berdasarkan data yang

dikumpulkan dapat dilihat skor

tertinggi adalah 80 dan skor terendah
65. Sedangkan nilai rata-rata pada skor yang diperoleh skor di atas adalah:

$$
\begin{aligned}
& M=\frac{\sum Y}{\mathrm{~N}} \\
& M=\frac{4605}{68} \\
& M=67,72
\end{aligned}
$$

Sesuai nilai rata-rata pemahaman makna kata berimbuhan yang diperoleh siswa yaitu 67,72 maka tingkat rata-rata siswa berada pada kategori" Baik“.

Untuk melakukan uji hipotesis yang sudah dirumuskan dalam penelitian maka dilakukan analisis dengan teknik korelasi Produc Moment. Teknik ini digunakan untuk melihat tingkat korelasi atau hubungan kedua variabel. Untuk mengetahui indeks korelasi variabel, maka ada beberapa tahap yang dilakukan, yaitu:

1. Membuat tabel kerja perhitungan antara variabel $\mathrm{X}$ dan Y.

2. Mencari angka indeks korelasi "r" Product Moment antara variabel $\mathrm{X}$ dan $\mathrm{Y}$. 
3. Memberikan interpretasi terhadap $\mathrm{r}_{\mathrm{xy}}$ serta menarik simpulannya

Berdasarkan penghitungan di atas, koefisien korelasi 0,388 dikategorikan hubungan rendah, artinya, penguasaan gaya bahasa metafora memiliki hubungan rendah dengan kemampuan menulis naskah pidato ekstemporan oleh Siswa Kelas X SMK Muhammadiyah 14 Siabu. Berdasarkan koefisien korelasi ini, signifikansinya akan diuji. Pengujian dilakukan dengan jalan mengonsultasikan harga $r_{\text {hitung }}$ dengan harga $\mathrm{r}_{\text {tabel }}$ Product Moment pada derajat kebebasan $(\mathrm{db})=68$ dengan taraf signifikansi 95\%. Dengan $\mathrm{db}=$ 68 diperoleh harga $r_{\text {tabel }}$ pada taraf signifikansi $95 \%$ adalah 0,374 . Jadi $\mathrm{r}_{\text {hitung }}>\mathrm{r}_{\text {tabel }}$ yakni: pada taraf signifikansi 95\% 0,388 > 0,374.

Sesuai dengan kriteria pengujian dengan uji "r" maka hubungan variabel $\mathrm{X}$ dengan $\mathrm{Y}$ pada penelitian ini merupakan hubungan yang signifikan, artinya, semakin baik penguasaan gaya bahasa metafora, maka semakin baik pula kemampuan siswa menulis naskah pidato ekstemporan.
Untuk analisis interpretasi akan diuraikan sebagai berikut:

1. Interpretasi secara kasar/ sederhana

Dengan berpedoman kepada pendapat Anas Sadjono: " Interpretasi angka indeks korelasi $\mathrm{r}$ product moment dengan secara kasar (sederhana), dapat dilakukan dengan membandingkan besarnya $r_{x y}$ (yaitu= 0,388) dengan nilai interpretasi.",

Nilai interpretasi korelasi $\mathrm{r}$ product moment dapat dilihat di tabel berikut:

\section{Tabel 4.4}

Nilai Interpretasi Korelasi r Product Moment

\begin{tabular}{|c|c|c|}
\hline No & $\begin{array}{c}\text { Nilai “r" } \\
\text { Product } \\
\text { Moment }\end{array}$ & $\begin{array}{c}\text { Tingkat } \\
\text { Interpretasi }\end{array}$ \\
\hline 1 & $0,000-0,200$ & Sangat lemah \\
\hline 2 & $0,200-0,400$ & Lemah \\
\hline 3 & $0,400-0,700$ & Sedang/ cukup \\
\hline 4 & $0,700-0,900$ & Tinggi \\
\hline 5 & $0,900-1,000$ & Sangat tinggi \\
\hline
\end{tabular}

Berdasarkan tabel di atas dapat diketahui bahwa nilai $r_{\text {hitung }}\left(r_{x y}=\right.$ 0,388) berada ditingkat korelasi lemah atau kurang. 
2. Interpretasi dengan menggunakan tabel kritik $\mathrm{r}$ product moment, interpretasi ini dilakukan dengan melihat hasil $r_{\text {hitung }}$ kemudian dibandingkan dengan nilai $r_{\text {tabel }}$ pada $\mathrm{dk}=\mathrm{N}-2$, untuk menguji taraf signifikan. Berdasarkan data yang telah diperoleh dapat diketahui $\mathrm{dk}=68-2=66$.

a. Jika " $r$ " lebih besar dari $r_{\text {tabel }}(r$ $>\mathrm{r}_{\text {tabel }}$ ) maka Ha diterima Ho ditolak.

b. Jika $r$ lebih kecil dari $\mathrm{r}_{\text {tabel }}(\mathrm{r}<$ $\mathrm{r}_{\text {tabel) }}$ maka Ha ditolak dan $\mathrm{Ho}$ diterima.

Akhirnya dapat disimpulkan bahwa hubungan penguasaan gaya bahasa metafora dengan keterampilan menulis naskah pidato ekstemporan siswa kelas X SMK Muhammadiyah 14 Siabu masih rendah atau lemah maka hipotesis dapat dikategorikan baik. Berdasarkan data-data yang telah dikumpulkan dan hasil penelitian, maka dapat disimpulkan sebagai berikut:

1. Gambaran pengguanaan gaya bahasa metafora siswa kelas $\mathrm{X}$ SMK Muhammadiyah 14 Siabu dikategorikan baik. Hal ini dapat dilihat dengan skor rata-rata yang diperoleh siswa yaitu 64,48 .

2. Kemampuan menulis naskah pidato ekstemporan siswa kelas X SMK Muhammadiya 14 Siabu dikategorikan baik. Sesuai dengan nilai rata-rata yang diperoleh siswa yaitu 67,72 .

3. Ada hubungan yang signifikan antara penguasaan gaya bahasa metafora dengan kemampuan menulis naskah pidato ekstempoaran siswa kelas $\mathrm{X}$ SMK Muhammadiyah 14 Siabu. Hal ini dapat dilihat pada uji hipotesis yang dilakukan pada data yang ditemukan, dimana hipotesis alternatif (Ha) dalam penelitian ini diterima, yaitu $\mathrm{Ho}=(0,374$ $<0,388) \mathrm{Ha}=(0,388>0,374)$.

\section{DAFTAR PUSTAKA}

Amri, Yusni Khairul. 2015. Bahasa Indonesia Pemahaman DasarDasar Bahasa Indonesia. Medan: Atap Buku Yogyakatra. Ali, Muhammad. 2008. Kamus Lengkap Bahasa Indonesia Moderen. Jakarta: Pustaka Amani Jakarta. 
Alwi, Hasan. 2007. Kamus Besar

Bahasa Indonesia (KBBI).

Jakarta: Balai Pustaka.

Arikunto, Suharsimi.2005Managemen

Penelitian. Jakarta: Rineka

Cipta. Berencana. Jakarta:

EGC. Cipta.

Arikunto Suharsimi. 2010. Prosedur

Penelitian Suatu Pendekatan

Praktik, Yokyakarta: Reneka

Cipta.

Dalman, H. 2011. Keterampilan Menulis. Bandar Lampung: PT Raja Gramedia Persada.

Keraf, Gorys. 1980. Diksi dan Gaya Bahasa. Jakarta: PT Gramedia Pustaka Utama.

Nurjamal, Daeng, dkk, 2011. Terampil Berbahasa, Bandung, Alfabeta.

Moelino, Anto , DKK. 1996. Kamus Pintar Bahasa Indonesia, Jakarta: Balai Pustaka.

Maulana, Afqi. 1999. Cara Berdiskusi / Mc dan Pidato. Surabaya: Putra Pelajar.

Poerwadarminta. 2003. Kamus Besar Bahasa Indonesia, Jakarta: Balai Pustaka.
Sumardiria, AS Haris. 2006. Bahasa

Jurnalistik. Bandung: Simbiosa Rekatama Media.

Sugiyono. 2008. Metode Penelitian Pendidikan Pendidikan Kuantitatif, Kualitatif, dan $R \&$ D. Bandung: Alfabeta.

Sugiyono. 2008. Metode Penelitian

Pendidikan. Bandung:

Alfabetha.

Tarigan, Hendry Guntur. 1982. Menulis Sebagai Suatu Keterampilan Berbahasa. Bandung: Angkasa. 